\title{
ВИВЧЕННЯ ПОТРЕБИ В НЕФОРМАЛЬНІЙ ОСВІТІ СЕРЕД МОЛОДШИХ СПЕЦІАЛІСТІВ 3 МЕДИЧНОЮ ОСВІТОЮ ЗАКЛАДІВ ОХОРОНИ ЗДОРОВ'Я ІВАНО-ФРАНКІВСЬКОЇ ОБЛАСТІ
}

\author{
Н. С. Ружило ${ }^{1}$, Н. О. Теренда \\ ${ }^{1}$ Комунальне некомерційне підприємство «Обласна клінічна лікарня \\ Івано-Франківської обласної ради" \\ ${ }^{2}$ Тернопільський національний медичний університет \\ імені І. Я. Горбачевського МОЗ Украӥни
}

\begin{abstract}
У статті проаналізовано потреби в неформальній освіті серед молодших спеціалістів з медичною освітою закладів охорони здоров’я Івано-Франківської області. Виявлено зацікавленість медичного персоналу у проведенні короткострокових фахових тренінгів, спрямованих на оволодіння як теоретичними, так і переважно практичними компетентностями. Впровадження інформальної освіти у процес набуття нових компетентностей та підвищення професійної майстерності молодших спеціалістів 3 медичною освітою є затребуваним напрямком сучасної системи безперервного професійного розвитку фахівців у сфері охорони здоров’я.
\end{abstract}

\section{STUDY OF THE NEED FOR INFORMAL EDUCATION AMONG NURSING STAFF OF THE HEALTH CARE INSTITUTIONS IN IVANO-FRANKIVSK REGION}

\author{
N. S. Ruzhylo ${ }^{1}$, N. O. Terenda ${ }^{2}$ \\ ${ }^{1}$ Ivano-Frankivsk Regional Clinical Hospital \\ ${ }^{2}$ I. Horbachevsky Ternopil National Medical University
}

\begin{abstract}
The article analyzes the need for informal education among nursing staff of the health care institutions in Ivano-Frankivsk region. The interest of medical staff in conducting short-term professional trainings aimed at mastering both theoretical and practical competencies was revealed. Implementation of informal education in the process of acquiring new competencies and improving the professional skills of medical staff is a popular direction of the modern system of continuous professional development of health care professionals.
\end{abstract}

Вступ. Вивчення міжнародного досвіду з питань розвитку медсестринства засвідчує, що раціональне використання сестринських кадрів сприяє значному покращенню якості, доступності та економічності надання медичної допомоги населенню, ефективному використанню ресурсів в охороні здоров'я, профілактиці захворювань [1]. Підвищення професійної майстерності та набуття нових компетентностей молодшими спеціалістами з медичною освітою одна із сучасних тенденцій професійної освіти.

Основна частина. Протягом лютого 2020 р. проведено онлайн-опитування серед молодших спеціалістів з медичною освітою закладів охорони здоров'я (3О3) Івано-Франківської області для визначення потреби в нових, неформальних методах підвищення про-

(ㄱ Н. С. Ружило, Н. О. Теренда, 2020 фесійної майстерності. В опитуванні взяли участь 200 респондентів.

Серед опитаних переважала вікова категорія 3049 років (70 \%), осіб старше 60 років було лише $2 \%$, що свідчить про наявність достатнього професійного досвіду серед молодших спеціалістів з медичною освітою (рис. 1).

Третина опитаних (34,3 \%) працює у КНП «Обласна клінічна лікарня Івано-Франківської обласної ради», 34,8 \% - у районних та міських лікарнях Івано-Франківської області, 17,7 \% - у центрах первинної медичної допомоги, решта - в інших закладах охорони здоров'я регіону.

Більшість медичних працівників надає допомогу в медичних закладах вторинного рівня надання медичної допомоги (42,2 \%), майже порівно первин- 


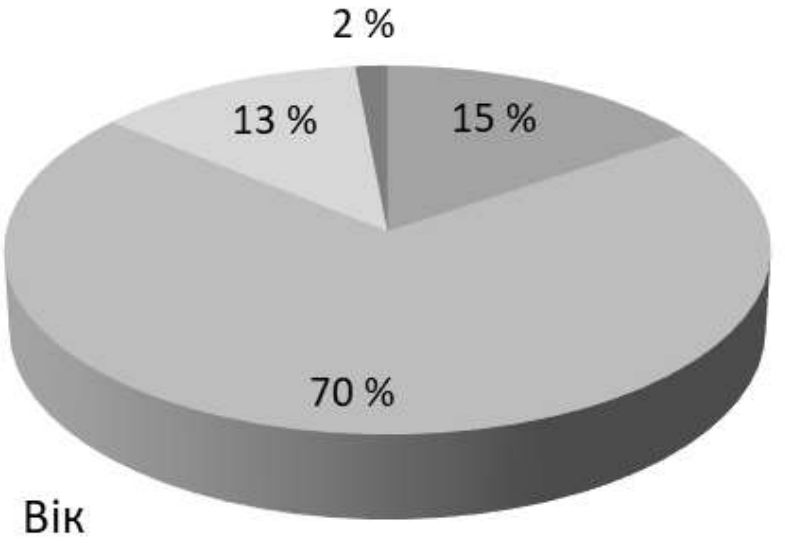

до 30 років

30-49 років

50-60 років

старше 60 років

Рис. 1. Поділ за віком опитаних молодших спеціалістів з медичною освітою закладів охорони здоров'я Івано-Франківської області.

ного (26,2 \%) та третинного (25,7\%) рівнів, а також у відділеннях екстреної медичної допомоги (1,6 \%), паліативної допомоги (1,1 \%) та інших. Більшість респондентів $(33,1 \%)$ працювала у соматичних стаціонарних відділеннях обласної, районних та міських лікарень області, 18,2 \% - у хірургічних операційними медичними сестрами та анестезистами, 11 \% - у поліклінічних відділеннях, 12,2 \% - у центрах первинної медичної допомоги як сімейні медичні сестри, 7,1 \% займали керівні посади в закладах охорони здоров'я.

Важливою функцією охорони здоров'я $\epsilon$ формування кадрових ресурсів, збільшення капіталу і впровадження нових технологій [2]. Про високий рівень професійної майстерності та кваліфікації медичного персоналу свідчить стаж професійної діяльності та кваліфікаційна категорія. Більшість молодших спеціалістів з медичною освітою працює в системі охорони здоров'я не менше 10 років. Стаж практичної роботи до 10-15 років був у $20 \%$ опитаних, 15-20 років - у $26,5 \%, 20-30$ років - у $21 \%$, більше 30 років - 13,5 \%, на відміну від 5-10 років - у 9,5 \%, 1-5 років - $8 \%$, до одного року - лише 1,5%. Така тривалість практичної діяльності зіставляється і з наявністю високих кваліфікаційних категорій. Так, вища кваліфікаційна категорія наявна у 60,5 \% опитаних, перша - у $15 \%$, друга - у $12 \%$, не мали кваліфікаційної категорії лише 12,5\%.

Відповідно до наказу Міністерства охорони здоров'я України від 23 листопада 2007 р № 742 «Про атестацію молодших спеціалістів з медичною освітою» та Постанови Кабінету Міністрів України від 28 березня 2018 р. № 302 «Про затвердження Положення про систему безперервного професійного розвитку фахівців у сфері охорони здоров'я», медичні працівники зобов'язані підвищувати свою професійну компетентність впродовж всього періоду діяльності у сфері медицини [3, 4]. На практиці на сьогодні медичні працівники проходять курси підвищення кваліфікації один раз на п'ять років із подальшою атестацією.

Згідно з проведеним опитуванням, молодші спеціалісти з медичною освітою закладів охорони здоров'я Івано-Франківської області проходили останні курси підвищення кваліфікації в термін від одного місяця до 5 років, лише 2,8 \% не проходили таких курсів взагалі, що пов'язано із невеликою тривалістю роботи в 303.

що таке постійно діючі курси підвищення кваліфікації для цієї категорії медичних працівників?

По-перше, це, як правило, відділення при медичних коледжах, в штаті яких основних працівників одиниці. Тобто основними викладачами для слухачів $\epsilon$ залучені працівники з різнопрофільних установ. Чи можна розраховувати в цій ситуації на висококласного спеціаліста, який знайде час для такої погодинної роботи в щільному графіку та достатньо великому навантаженні на основній роботі (операції, консультації, прийоми)?

По-друге, слухачі курсів стикаються з проблемами організованого проживання на 1-2 місяці (залежно від проходження підвищення кваліфікації або спеціалізації) та матеріальними затратами (лише частина керівників медичних закладів знаходить можливість оплатити відрядні своїм працівникам).

По-третє, частота проходження курсів. Фактично проходження курсів молодшими спеціалістами 3 медичною освітою плануються «під» проходження ними атестації на присвоєння кваліфікаційних категорій. Тобто один раз на п'ять років медичні сестри, фельдшери, акушери та лаборанти підвищують свою кваліфікацію шляхом проходження місячного навчання на курсах. Якою може бути якість знань, здобутих один раз на 5 років, у час інтенсивного прогресу в медичній галузі, коли відкривають нові спеціальності, установи працюють на обладнанні, яке змінюється що декілька років, коли для навчання використовують цикли спеціалізації та удосконалення, в які не так часто вносять відповідні зміни.

У процесі дослідження проаналізовано інформаційні джерела, де молодші спеціалісти з медичною освітою здобувають нові компетентності у межах професійної діяльності (табл. 1). 
Таблиця 1. Інформаційні джерела для підвищення професійної майстерності серед молодших спеціалістів 3 медичною освітою Івано-Франківської області

\begin{tabular}{|l|c|c|c|c|}
\hline \multicolumn{1}{|c|}{ Інформаційні джерела } & \multicolumn{2}{c|}{ Використовують } & \multicolumn{2}{c|}{ Не використовують } \\
\cline { 2 - 5 } & абс. & $\%$ & \multicolumn{2}{c|}{ абс. } \\
\hline Курси тематичного вдосконалення один раз на 5 років & 156 & 78,0 & 17 & 8,5 \\
\hline Спеціальні короткотривалі тренінги & 83 & 41,5 & 31 & 15,5 \\
\hline Методичні рекомендації & 111 & 55,5 & 7 & 3,5 \\
\hline Спеціальна професійна література & 103 & 51,5 & 19 & 9,5 \\
\hline Практичний досвід набутий у спілкуванні з колегами & 114 & 57,0 & 5 & 2,5 \\
\hline Практичний досвід набутий самостійно & 124 & 62,0 & 4 & 2,0 \\
\hline
\end{tabular}

Отримані дані свідчать, що вже на сьогодні молодші спеціалісти з медичною освітою Івано-Франківської області стараються здобути професійні знання не лише на курсах тематичного вдосконалення, а й використовуючи само- та взаємоосвіту, спеціальну професійну літературу та методичні рекомендації.

Також у нашому дослідженні вивчено методи навчання, яким надали б перевагу молодші спеціалісти з медичною освітою для здобуття нових компетентностей у межах професійної діяльності (табл. 2).

Отримані дані свідчать про зацікавленість медичного персоналу в проведенні короткотривалих, але фахових тренінгів, спрямованих на оволодіння як теоретичними, так і переважно практичними компетентностями $(81,0 \%)$.

При цьому 59,4 \% опитаних надають перевагу очній формі навчання. Більшості респондентів імпонує практичне навчання. Так, лише 31,0 \% надають перевагу лекціям. Для набуття та підвищення професійної майстерності респонденти вважають більш необхідним практичне проведення занять (88,5 \%), використання ділових ігор, тренінгів із психологічної підготовки (46,5 \%), вивчення закордонного досвіду (70,0\%).

Таблиця 2. Методи навчання для здобуття нових компетентностей у межах професійної діяльності серед молодших спеціалістів з медичною освітою Івано-Франківської області

\begin{tabular}{|c|c|c|}
\hline Методи навчання & Aбc. & $\%$ \\
\hline Курси тематичного вдосконалення & 69 & 34,5 \\
\hline Спеціальні короткотривалі тренінги з оволодіння практичними навичками & 162 & 81,0 \\
\hline Методичні рекомендації & 66 & 33,0 \\
\hline Спеціальна професійна література & 78 & 39,0 \\
\hline Участь у фахових семінарах, практичних конференціях & 144 & 72,0 \\
\hline Участь у симуляційних тренінгах, майстер-класах & 139 & 69,5 \\
\hline Дистанційне навчання & 77 & 38,5 \\
\hline Стажування в інших клініках, у тому числі в закордонних & 148 & 74,0 \\
\hline
\end{tabular}

Висновки. Впровадження інформальної освіти у процес набуття нових компетентностей та підвищення професійної майстерності молодших спеціалістів 3

\section{СПИСОК ЛІТЕРАТУРИ}

1. Чернишенко Т. І. Міжнародне співробітництво у медсестринській справі / Т. І. Чернишенко // Медсестринство в Україні. - 2000. - № 1. - С. 2-8.

2. Пілотний проект «реформа медичного обслуговування»: цілі та кроки реалізації / В. М. Лехан, В. Г. Гінзбург, Г. О. Слабкий та ін. // Україна. Здоров'я нації. - 2010. № 3 (15). - С. 7-15.

3. Про атестацію молодших спеціалістів з медичною освітою : наказ МОз України від 23.11.2007 р. № 742 медичною освітою є затребуваним напрямком сучасної системи безперервного професійного розвитку фахівців у сфері охорони здоров'я.

[Електронний ресурс]. - Режим доступу : https://zakon. rada.gov.ua/laws/show/z1368-07.

4. Про затвердження Положення про систему безперервного професійного розвитку фахівців у сфері охорони здоров'я : Постанова Кабінету Міністрів України від 28 березня 2018 р. № 302 [Електронний ресурс]. Режим доступу : https://zakon.rada.gov.ua/laws/show/3022018-п. 